\title{
Electrocatalytic Study of Carbon Dioxide Reduction By Co(TPP)Cl Complex
}

\author{
Khalaf Alenezi \\ Department of Chemistry, Faculty of Science, University of Hail, Hail, Saudi Arabia \\ Correspondence should be addressed to Khalaf Alenezi; khalaf260@yahoo.com
}

Received 15 November 2015; Accepted 1 December 2015

Academic Editor: Liviu Mitu

Copyright (C) 2016 Khalaf Alenezi. This is an open access article distributed under the Creative Commons Attribution License, which permits unrestricted use, distribution, and reproduction in any medium, provided the original work is properly cited.

\begin{abstract}
Carbon dioxide $\left(\mathrm{CO}_{2}\right)$ is notorious for being a greenhouse gas and is the most important cause of global warming. However, it can be converted into useful products as it is a source of carbon. Reduction of $\mathrm{CO}_{2}$ is therefore an attractive research topic for many chemists. Different methods of electrocatalytic reduction of $\mathrm{CO}_{2}$ have been reported previously. Since $\mathrm{CO}_{2}$ is very stable, the direct electroreduction of $\mathrm{CO}_{2}$ into $\mathrm{CO}$ requires high potential at $-2.2 \mathrm{~V}$ versus $\mathrm{Ag} / \mathrm{AgCl}$. In this work, $\mathrm{CO}_{2}$ reduction was carried out by the photoelectrocatalysis of $\mathrm{CO}_{2}$ in the presence of cobalt(III)tetraphenylporphyrin $[\mathrm{Co}(\mathrm{TPP}) \mathrm{Cl}]$ at $-1.85 \mathrm{~V}$ with a current efficiency of $71 \%$. At illuminated p-type silicon photocathode, the reduction of $\mathrm{CO}_{2}$ into $\mathrm{CO}$ was performed at a potential of $300 \mathrm{mV}$ which is positive. However, at the same conditions, potential of $-1.55 \mathrm{~V}$ with a current efficiency of $c a 65 \%$ is required for the carbon electrode.
\end{abstract}

\section{Introduction}

The increasing amount of carbon dioxide $\left(\mathrm{CO}_{2}\right)$ over the past years may affect the environment adversely due to the fact that it is a greenhouse gas and can lead to global warming. In the air, $\mathrm{CO}_{2}$ is a final product of combustion of carbon-containing compounds and represents fully oxidized carbon. It is thermodynamically very stable and it requires a lot of energy to break its $\mathrm{C}-\mathrm{O}$ bonds. However, there are four different methods for $\mathrm{CO}_{2}$ splitting: enzymatic $[1,2]$, electrochemical (electrocatalytic) reduction $[3,4]$, photoreduction $[5,6]$, and abstraction of an oxygen atom from a $\mathrm{CO}_{2}$ molecule by coordination complexes [7]. The conversion of $\mathrm{CO}_{2}$ into valuable products is challenging as it requires a lot of energy [8-10]. Photosynthesis, photocatalytic, and electrochemical reduction of $\mathrm{CO}_{2}$ are the effective processes to use $\mathrm{CO}_{2}$ as a carbon source and convert it into useful products. Energy is required for all these processes, such as requirement of electricity in electrochemical reduction process [11]. $\mathrm{CO}_{2}$ has been converted into chemicals (such as formic acid) and fuels (such as methanol, methane, and carbon monoxide (CO)) previously [12-14]. Photochemical conversion of $\mathrm{CO}_{2}$ to fuels or valuable chemicals using renewable solar energy can decrease the amount of $\mathrm{CO}_{2}$ in the atmosphere [15].

Recycling atmospheric $\mathrm{CO}_{2}$, by its capture and subsequent reduction to valuable products and liquid fuels, is an increasingly important research area. It is possible to drive the half-cell reaction $\left(\mathrm{CO}_{2}+2 \mathrm{H}^{+}+2 \mathrm{e}^{-} \rightarrow \mathrm{CO}+\mathrm{H}_{2} \mathrm{O}\right)$ under visible light illumination at a p-type silicon (p-Si) photocathode using a catalyst $[16,17]$.

A light assisted generation of syngas $\left(\mathrm{H}_{2}: \mathrm{CO}=2: 1\right)$ from $\mathrm{CO}_{2}$ and water can be achieved by using $\mathrm{p}$-Si/catalyst. In the system, water is reduced heterogeneously on $\mathrm{p}$-Si surface and $\mathrm{CO}_{2}$ is reduced homogeneously by the catalyst (Scheme 1) [17, 18 .

The field of electrocatalytic reduction of $\mathrm{CO}_{2}$ by metal complexes has been studied extensively by many researchers [19-22]. Homogeneous transition-metal catalysts, such as Ru, $\mathrm{Re}, \mathrm{Co}$, and $\mathrm{Ni}$ complexes, have been used to reduce the $\mathrm{CO}_{2}$ molecule by a multielectron reduction process [23-25]. $\mathrm{CO}_{2}$ reduction by tricarbonyl rhenium(I) complex was first reported by Hawecker and coworkers [26], and the mechanism of such reactions have been studied previously [2630]. The most efficient catalyst $\left[\operatorname{Re}(\mathrm{bpy})(\mathrm{CO})_{3}\left\{\mathrm{P}(\mathrm{OEt})_{3}\right\}\right]^{+}$ was used for the selective photoreduction of $\mathrm{CO}_{2}$ to $\mathrm{CO}$ 


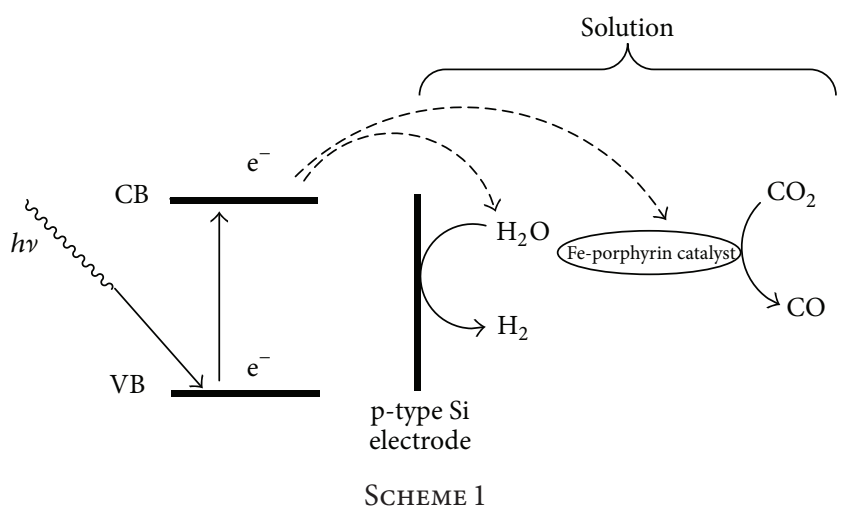

in a homogeneous system [27]. The drawback of using rhenium complex as a catalyst is that it reacts with $\mathrm{CO}_{2}$ very slowly [28-32]. Binuclear rhenium(I) complexes with saturated bridging ligands have been synthesized for the photocatalytic $\mathrm{CO}_{2}$ reduction [33]. Recently, the synthesis of dinuclear rhenium complexes of the 2,4,6-tris(2-pyridyl)1,3,5-triazine (tptz) ligand and catalytic activity of tptz, as a bis(bidentate) ligand or as a bi- and tridentate chelating ligand, has been reported [34].

The reduction of $\mathrm{CO}_{2}$ to $\mathrm{CO}$ using visible light can be used to cycle $\mathrm{CO}_{2}$ gas $[8,17,35-38]$. Hawecker and coworkers used $\operatorname{Re}(\mathrm{I})$ pyridyl complex as a catalyst for $\mathrm{CO}_{2}$ reduction into $\mathrm{CO}$ [26]. In addition, the same reaction has been carried out by using sacrificial amine as an electron source $[27,30] . \operatorname{Re}\left(4,4-\mathrm{But}_{2}\right.$ bpy $)(\mathrm{CO})_{3} \mathrm{Cl}$ has been used as a catalyst for the same purpose at p-type silicon photocathodes when illuminated with visible light giving a photo-voltage of $c a 600 \mathrm{mV}$. Thus, it makes the reduction of $\mathrm{CO}_{2}$ possible at potentials of $-1.2 \mathrm{~V}$ to $-1.4 \mathrm{~V}$ versus saturated calomel electrode (SCE). A current efficiency of $97 \%$ was achieved under illumination. The duration of electrolysis was $3 \mathrm{~h}$. However, attempts have been made to replace rhenium with more abundant metals for organometallic complexes due to the fact that rhenium is a rare metal found on earth $[10,39$, 40].

Tetraphenylporphyrin iron chloride complex ( $\mathrm{Fe}(\mathrm{TPP}) \mathrm{Cl}$ ) was previously used for $\mathrm{CO}_{2}$ reduction to $\mathrm{CO}$ and was claimed to be an efficient electrocatalyst for $\mathrm{CO}_{2}$ reduction. 95\% of current efficiency was reported and $\mathrm{CO}$ was reported to have high selectivity compared to $\mathrm{H}_{2}$ at a mercury pool cathode when 2,2,2-trifluoroethanol $\left(\mathrm{CF}_{3} \mathrm{CH}_{2} \mathrm{OH}\right)$ was used as a proton source. Reduction of $\mathrm{CO}_{2}$ to $\mathrm{CO}$ was carried out in a visible light at illuminated p-type $\mathrm{Si}$ photocathode using $\mathrm{Fe}(\mathrm{TPP}) \mathrm{Cl}$ in the presence of $\mathrm{CF}_{3} \mathrm{CH}_{2} \mathrm{OH}$ as a proton source gave a current efficiency $>90 \%$ and a high selectivity over $\mathrm{H}_{2}$ formation. The potential of $c a-1.2 \mathrm{~V}$ versus SCE was required under illumination. In the dark, on vitreous carbon, a potential of $-1.85 \mathrm{~V}$ versus SCE was required. Iron(0)pentaflourotetraphenylporphyrin (Fe(PFTPP)Cl) was reported to be more positive potential than $\mathrm{Fe}(\mathrm{TPP}) \mathrm{Cl}$, because the strong electron withdrawing fluorogroups shifted the potential for electrocatalysis about $400 \mathrm{mV}$ positive compared to that of $\mathrm{Fe}(\mathrm{TPP}) \mathrm{Cl}$ [41].
The economic and efficient conversion of overabundant $\mathrm{CO}_{2}$ into sources of fuel by means of renewable solar energy is one of the important objectives [42-45]. This work presents the electrochemical catalysis of $\mathrm{CO}_{2}$ reduction into $\mathrm{CO}$ by cobalt(III)tetraphenylporphyrin $[\mathrm{Co}(\mathrm{TPP}) \mathrm{Cl}]$ at carbon and illuminated p-type Si electrodes.

\section{Materials and Methods}

Chemicals, solvents, $\mathrm{Co}(\mathrm{TPP}) \mathrm{Cl}$, and $\mathrm{CF}_{3} \mathrm{CH}_{2} \mathrm{OH}$ were purchased from Aldrich and used as received. Methyl cyanide $\left(\mathrm{CH}_{3} \mathrm{CN}\right)$ was purified by distillation over calcium hydride. The single crystal B-doped p-type Si $\left(1-10 \mathrm{~cm}^{-1}\right.$, (111) face, thickness $500-550 \mu \mathrm{m}$ ) was supplied by Silicon Materials (Germany). The ohmic contacts were made using Ga-In eutectic and silver epoxy resin by the method of Tamaki et al. [43]. The photoelectrochemical cell was described earlier [45].

Cyclic voltammetric experiments were carried out using an Autolab PGSTAT 30 potentiostat. A conventional threeelectrode arrangement was employed, consisting of a vitreous carbon working electrode, a platinum wire as the auxiliary electrode, and $\mathrm{Ag}^{+} / \mathrm{AgCl}$ as a reference electrode.

The electrolysis cells were degassed with argon gas to remove oxygen. The cell was filled with an electrolyte (a solvent containing $\left.0.2 \mathrm{M}\left[\mathrm{Bu}_{4} \mathrm{~N}\right]\left[\mathrm{BF}_{4}\right]\right)$. The volume of electrolyte was $14 \mathrm{~mL}$, out of which $5 \mathrm{~mL}$ occupied the working electrode compartment. About 9-10 mL gas phase took place at the working electrode part. $0.35 \mathrm{mM}$ catalyst $\mathrm{Co}(\mathrm{TPP}) \mathrm{Cl}$ was added and dissolved in $5 \mathrm{~mL}$ dry $\mathrm{CH}_{3} \mathrm{CN}$ and stirred under Ar in electrochemical cell which was under Ar. Cyclic voltammetric measurements of $\mathrm{Co}(\mathrm{TPP}) \mathrm{Cl}$ were carried out under Ar; then, the solution was bubbled with $\mathrm{CO}_{2}$ (saturated with $\mathrm{CO}_{2}$ ). The cyclic voltammetry of $\mathrm{Co}(\mathrm{TPP}) \mathrm{Cl}$ was done under $\mathrm{CO}_{2}$ atmosphere to know the reduction catalytic $\mathrm{CO}_{2} \cdot \mathrm{CF}_{3} \mathrm{CH}_{2} \mathrm{OH}$ was added to improve both efficiency and catalyst life time, without any significant formation of $\mathrm{H}_{2}$.

The electrolysis was carried out at the fitting potential and the current was recorded during the course of electrolysis verses the time. In addition, the charge passed was recorded. The electrolysis was stopped when the current decayed after $1.4 \mathrm{~h}$.

\section{Results and Discussion}

The electrocatalytic behavior of $\mathrm{Co}(\mathrm{TPP}) \mathrm{Cl}$ was tested by cyclic voltammetry in the absence of $\mathrm{CO}_{2}$.

Figure 1 shows the typical cyclic voltammetry of $\mathrm{Co}$ (TPP) $\mathrm{Cl}$ at carbon electrode in the absence of $\mathrm{CO}_{2}$. The cyclic voltammetry of the complex exhibits two successive reduction waves. The first wave is reversible corresponding to $\mathrm{Co}(\mathrm{II}) / \mathrm{Co}(\mathrm{I})^{-}$(one electron) at $E_{1 / 2}=-0.76 \mathrm{~V}$, and the second wave is irreversible corresponding to $\mathrm{Co}(\mathrm{I})^{-} / \mathrm{Co}(0)^{2-}$ (two electrons, one electron for second process of $\mathrm{Co}(\mathrm{TPP}) \mathrm{Cl}$, $E_{p}=-1.98$ versus $\mathrm{V}$, and maybe the farther electron related to reduction of complex); potentials cited are versus $\mathrm{Ag} / \mathrm{AgCl}$.

Figure 2 shows the different scan rate in $0.1 \mathrm{M}$ $\left[\mathrm{Bu}_{4} \mathrm{~N}\right]\left[\mathrm{BF}_{4}\right]-95 \% \mathrm{MeCN}+5 \% \mathrm{DMF}$ at vitreous carbon 


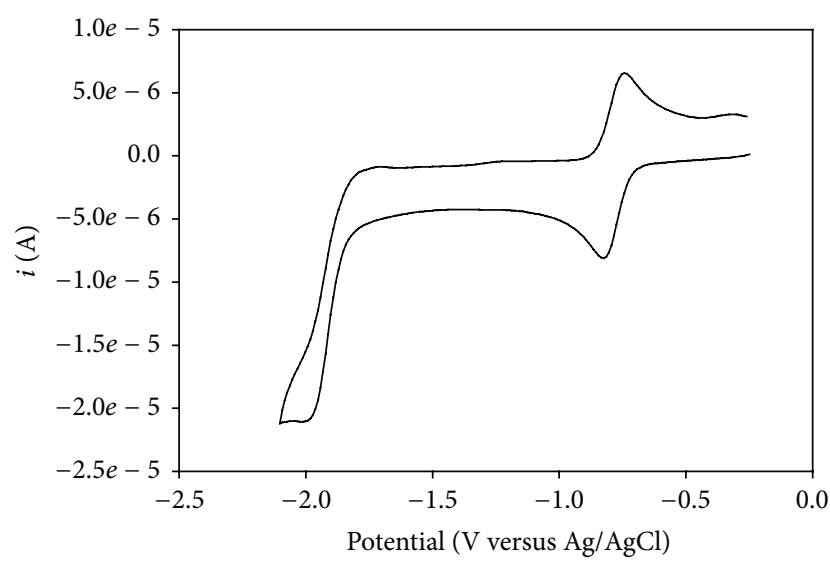

Figure 1: Cyclic voltammetry of $0.20 \mathrm{mM} \mathrm{Co}(\mathrm{TPP}) \mathrm{Cl}$ in $0.1 \mathrm{M}$ $\left[\mathrm{Bu}_{4} \mathrm{~N}\right]\left[\mathrm{BF}_{4}\right]-95 \% \mathrm{MeCN}+5 \% \mathrm{DMF}$, scan rate $100 \mathrm{mVs}^{-1}$ at vitreous carbon electrode under Ar.

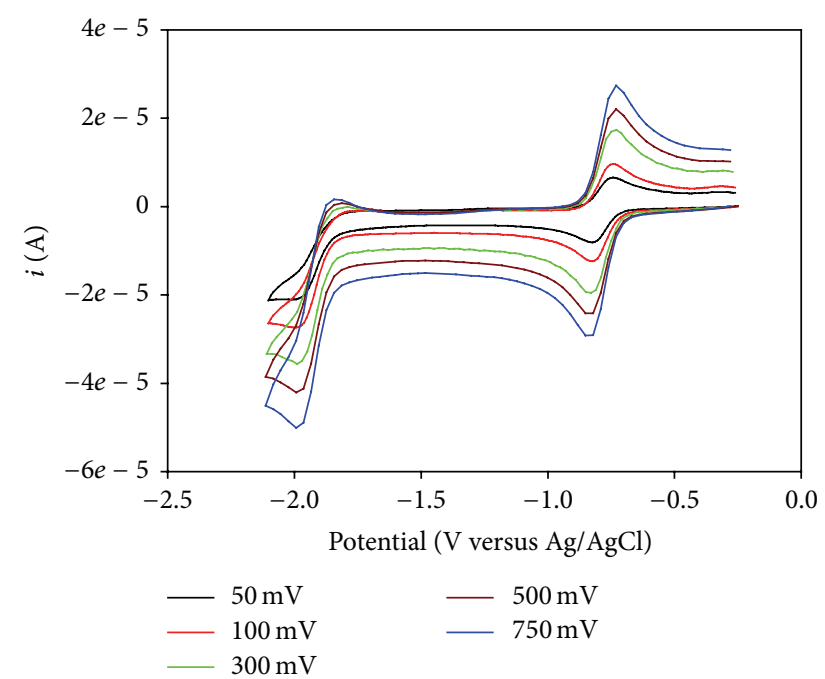

Figure 2: Cyclic voltammograms of $0.20 \mathrm{mM} \mathrm{Co}(\mathrm{TPP}) \mathrm{Cl}$ at carbon vitreous electrode, different scan rate in $0.1 \mathrm{M}\left[\mathrm{Bu}_{4} \mathrm{~N}\right]\left[\mathrm{BF}_{4}\right]-95 \%$ $\mathrm{MeCN}+5 \%$ DMF.

and Figure 3 shows the plots of $i_{p}$ red versus $n^{1 / 2}$ of the first and second processes of $\mathrm{Co}(\mathrm{TPP}) \mathrm{Cl}$, which are diffusioncontrolled and involve an electrochemically reversible one-electron transfer. The plot of peak current ${ }^{{ }} i_{p}$ red versus $n^{1 / 2}$ is linear which means no complicated mass transfer control of one electron-transfer rate. The diffusion of first wave is calculated according to the following:

$$
\begin{gathered}
i=7.4 \times 10^{-6} \mathrm{~A} \\
I=1.04 \times 10^{-4} \mathrm{~A} \cdot \mathrm{cm}^{-2}
\end{gathered}
$$

Area of electrode is $0.071 \mathrm{~cm}^{2}$

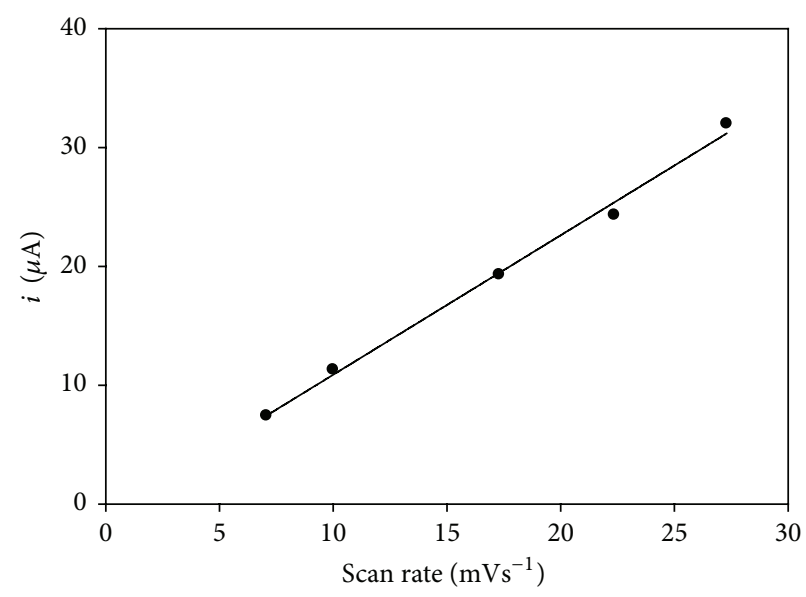

Figure 3: The plots of $i_{p}{ }^{\text {red }}$ versus $n^{1 / 2}, \operatorname{Co}(\mathrm{I})^{-1} / \mathrm{Co}(0)^{-2}$ reduction wave.

$$
I_{p}=-\left(2.69 \times 10^{5}\right) n^{3 / 2} D^{1 / 2} v^{1 / 2}
$$

Randles-Sevcik Equation

$$
D=1.2 \times 10^{-5} \mathrm{~cm}^{2} \mathrm{~s}^{-1} \text {. }
$$

3.1. Electrocatalytic Reduction of $\mathrm{CO}_{2}$ by $\mathrm{Co}(\mathrm{TPP}) \mathrm{Cl}$ on Vitreous Carbon and p-Type Si Electrodes. Figure 4(a) shows the electrocatalytic reduction of $\mathrm{CO}_{2}$ by $\mathrm{Co}(\mathrm{TPP}) \mathrm{Cl}$ on vitreous carbon, under argon. The current density of second reduction of $\mathrm{Co}$ (TPP) $\mathrm{Cl}$ is around $2.24 \times 10^{-4} \mathrm{~A} \cdot \mathrm{cm}^{-2}$. In the same figure, the cyclic voltammetry of the catalyst shows that $\mathrm{CO}_{2}$ interacts with the reduced catalyst. The second wave process increased in height and became irreversible under $\mathrm{CO}_{2}$, and the catalytic current density increased to $1.76 \times 10^{-3} \mathrm{~A} \cdot \mathrm{cm}^{-2}$.

As known, the direct reduction of $\mathrm{CO}_{2}$ at vitreous carbon electrode is around $-2.2 \mathrm{~V}$ versus $\mathrm{Ag} / \mathrm{AgCl}$. In the presence of $\mathrm{Co}$ (TPP) $\mathrm{Cl}$, the carbon $\mathrm{CO}_{2}$ shifted to $-1.85 \mathrm{~V}$ which is more positive in comparison with the direct reduction. At p-type Si electrode, the second wave reduction of $\mathrm{Co}(\mathrm{TPP}) \mathrm{Cl}$ shifted to a more positive value $c a 300 \mathrm{mV}$ under illumination of light (Figure 4(b) in the absence and presence of $\mathrm{CO}_{2}$ ).

Figure 5 shows the comparison of cyclic voltammetry of $\mathrm{Co}(\mathrm{TPP}) \mathrm{Cl}$ at p-type $\mathrm{Si}$ electrode in dark and light which proves the shifting of potential in the presence of light around $300 \mathrm{mV}$.

3.2. Preparative-Scale Electrolysis. Preparative bulk photoelectrosynthesis of $\mathrm{CO}$ on the p-type $\mathrm{Si}$ photocathode was performed in $1 \mathrm{M}\left[\mathrm{Bu}_{4} \mathrm{~N}\right]\left[\mathrm{BF}_{4}\right]-95 \% \mathrm{MeCN}+5 \% \mathrm{DMF}$ at room temperature in an $\mathrm{H}$-type in the presence of $0.2 \mathrm{mM}$ $\mathrm{Co}$ (TPP) $\mathrm{Cl}$ and $0.28 \mathrm{mM} \mathrm{CF}_{3} \mathrm{CH}_{2} \mathrm{OH}$. The gas chromatography (GC-TCD) confirmed the formation of $\mathrm{CO}$ with a current efficiency of $\mathrm{ca} 65 \%$. During the course of $1.4 \mathrm{~h}(-1.55 \mathrm{~V}$ versus $\mathrm{Ag} / \mathrm{AgCl}$ ), the charge passed was $4.18 \mathrm{C}$, the yield of $\mathrm{CO}$ was $14 \mu$ moles, and $\mathrm{ca} 10 \%$ amount of hydrogen was produced as a by-product (Figure 6).

In a separate experiment at the same conditions, the bulk electrolysis at carbon electrode was carried out at $-1.85 \mathrm{~V}$ 


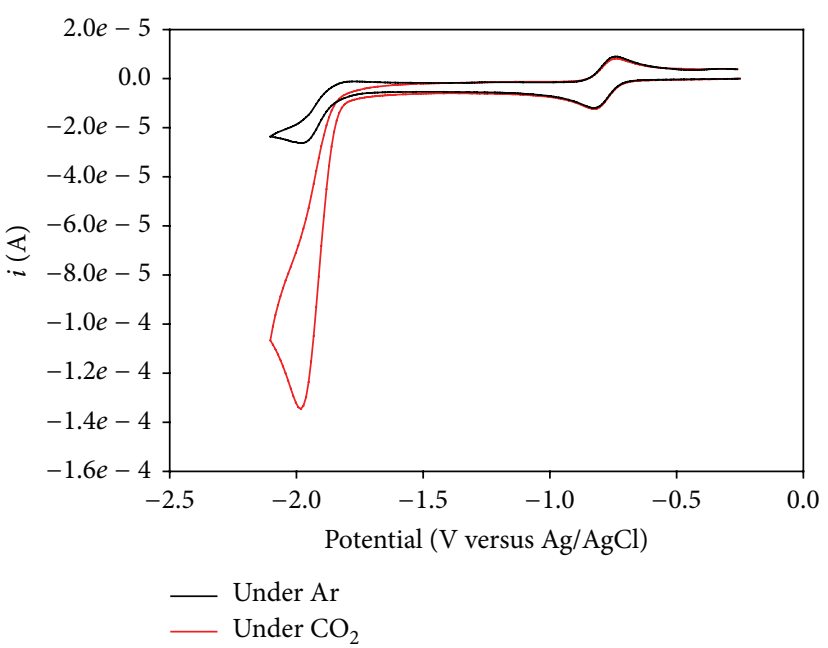

(a)

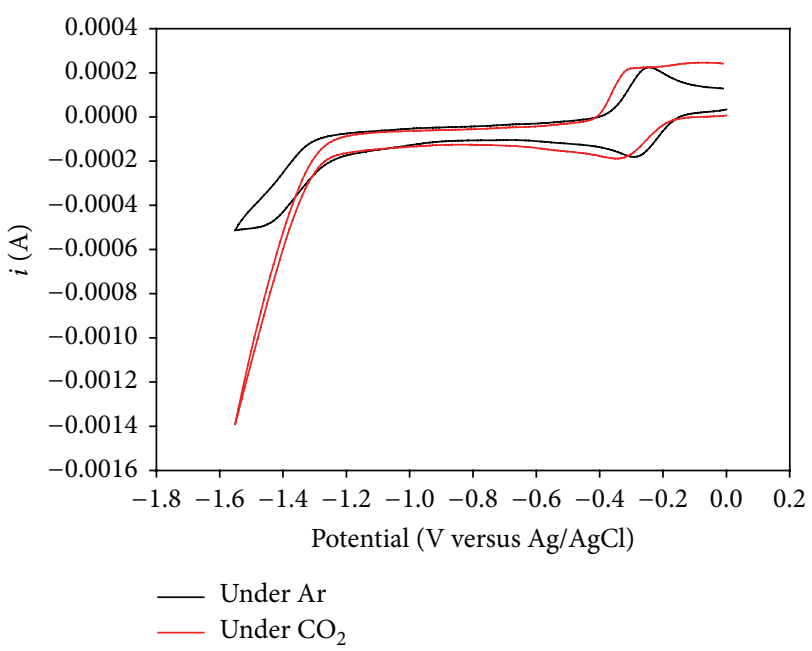

(b)

Figure 4: Cyclic voltammetry of $0.20 \mathrm{mM} \mathrm{Co}(\mathrm{TPP}) \mathrm{Cl}$ in $0.1 \mathrm{M}\left[\mathrm{Bu}_{4} \mathrm{~N}\right]\left[\mathrm{BF}_{4}\right]-95 \% \mathrm{MeCN}+5 \% \mathrm{DMF}$, scan rate $100 \mathrm{mVs}^{-1}$ (a) at a vitreous carbon electrode and (b) at illuminated $1-10 \mathrm{ohm} \mathrm{cm}^{-1}$ p-type Si electrode.

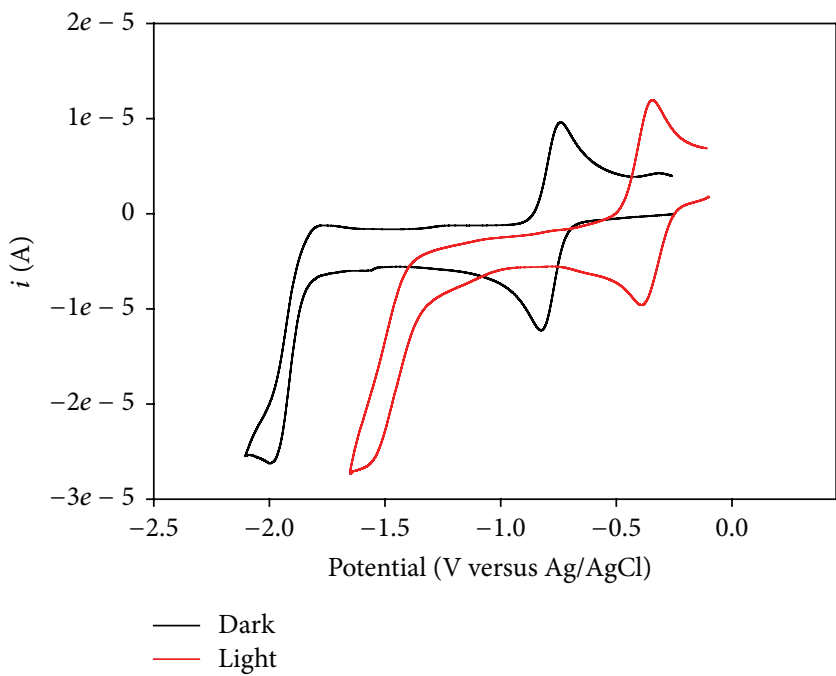

Figure 5: Cyclic voltammetry of $0.20 \mathrm{mM} \mathrm{Co(TPP)Cl}$ in $0.1 \mathrm{M}$ $\left[\mathrm{Bu}_{4} \mathrm{~N}\right]\left[\mathrm{BF}_{4}\right]-95 \% \mathrm{MeCN}+5 \% \mathrm{DMF}$, scan rate $100 \mathrm{mVs}^{-1}$ at $\mathrm{p}$-type Si electrode in dark and at illuminated p-type Si electrode under Ar.

versus $\mathrm{Ag} / \mathrm{AgCl} . \mathrm{CO}_{2}$ was converted into $\mathrm{CO}$ with a current efficiency of $c a 71.6 \%$, where the yield of CO was $19 \mu$ moles and the charge passed was $5.3 \mathrm{C}$. Also, a small amount of hydrogen was obtained which can be ignored. The current efficiency to produce $\mathrm{CO}$ at both carbon and p-type $\mathrm{Si}$ electrodes is smaller but the amount of hydrogen is different which may be because of coupling of homogeneous catalysts for the reduction of $\mathrm{CO}_{2}$ with heterogeneity of small amount of $\mathrm{H}_{2} \mathrm{O}$. Reduction of $\mathrm{CO}_{2}$ by photocathode at p-type $\mathrm{Si}$ electrode is shown in Figure 7 and the course of electrolysis was $1.4 \mathrm{~h}$.

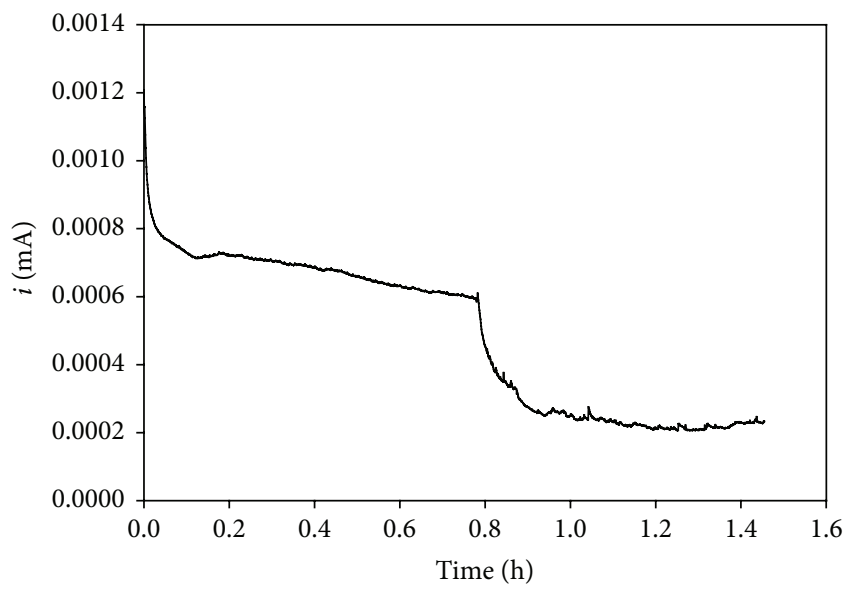

Figure 6: The current versus time: $0.2 \mathrm{mM} \mathrm{Co(TPP)Cl}$ in the presence of $\mathrm{CO}_{2}$ and $0.28 \mathrm{M} \mathrm{CF}_{3} \mathrm{CH}_{2} \mathrm{OH}$ in $\mathrm{MeCN}-5 \% \mathrm{DMF}$ containing $0.1 \mathrm{M}\left[\mathrm{Bu}_{4} \mathrm{~N}\right]\left[\mathrm{BF}_{4}\right]$, at p-type Si electrode.

Table 1 summarises the results of both electrocatalysis and photoelectrocatalysis of $\mathrm{CO}_{2}$ reduction by $\mathrm{Co}(\mathrm{TPP}) \mathrm{Cl}$ at carbon and p-type Si electrodes.

\section{Conclusion}

It has been shown that the $\mathrm{CO}_{2}$ reduction can be achieved by using a simple cobalt porphyrin complex as a catalyst in the electroreduction that is carried out in dark (carbon electrode) and under illumination (p-type Si electrode). At carbon electrode, cobalt porphyrin catalyzes conversion of $\mathrm{CO}_{2}$ to $\mathrm{CO}$ with the current efficiency of $72 \%$. On the other hand, the current efficiency of $\mathrm{CO}_{2}$ to $\mathrm{CO}$ reduction was only $65 \%$ at p-type Si electrode in the presence of cobalt porphyrin. However, $\mathrm{CF}_{3} \mathrm{CH}_{2} \mathrm{OH}$ was added to improve the catalysis of $\mathrm{CO}_{2}$ reduction. 
TABLE 1: Current efficiencies and turnover numbers of electrocatalytic reduction of $\mathrm{CO}_{2}$ catalyzed by $\mathrm{Co}(\mathrm{TPP}) \mathrm{Cl}$ at both carbon and p-type Si electrodes. T.N. $=$ moles of product $/$ moles of catalyst.

\begin{tabular}{lccccccc}
\hline Electrode & $\begin{array}{c}\text { CPE potential } \\
\text { (SCE) }\end{array}$ & $\begin{array}{c}\text { Number of } \\
\text { moles of } \\
\text { catalyst } \\
\mu \text { mole }\end{array}$ & $\begin{array}{c}\text { Time of } \\
\text { experiment/h }\end{array}$ & $\begin{array}{c}\text { Charge } \\
\text { coulomb/C }\end{array}$ & $\begin{array}{c}\text { Current } \\
\text { efficiency* } \\
\text { CO }\end{array}$ & $\begin{array}{c}\text { T.N. CO } \\
\begin{array}{c}\text { Number of } \\
\text { CO } \\
\mu \text { moles }\end{array}\end{array} \begin{array}{c}\text { Current } \\
\text { efficiency } \\
\mathrm{H}_{2}\end{array}$ \\
\hline Carbon & -1.85 & 1 & 1.4 & 5.4 & 72 & 19 & 19 \\
p-type $\mathrm{Si}$ & -1.55 & 1 & 1.4 & 4.2 & 65 & 13.9 & 13.9 \\
\hline
\end{tabular}

${ }^{*}$ The rest of current efficiency was unknown which might have been consumed by conversion of $\mathrm{CO}_{2}$ into oxalate or formate. Saveant and coworker reported that $\mathrm{CO}_{2}$ will be converted to oxalate or formate in the presence of a weak acid [42], or by decomposition of catalyst.

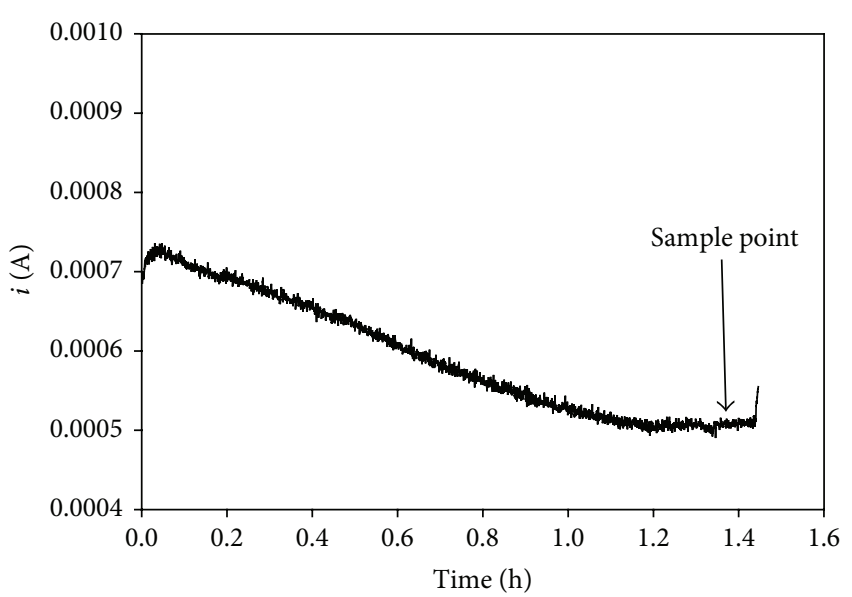

FIgURE 7: The current versus time: $0.2 \mathrm{mM} \mathrm{Co}(\mathrm{TPP}) \mathrm{Cl}$ in the presence of $\mathrm{CO}_{2}$ and $0.28 \mathrm{M} \mathrm{CF}_{3} \mathrm{CH}_{2} \mathrm{OH}$ in $\mathrm{MeCN}-5 \% \mathrm{DMF}$ containing $0.1 \mathrm{M}\left[\mathrm{Bu}_{4} \mathrm{~N}\right]\left[\mathrm{BF}_{4}\right]$, at carbon electrode.

Under illumination at p-type Si electrode (boron-doped p-type $\mathrm{H}$-terminated silicon), and in presence of cobalt porphyrin, the reduction of $\mathrm{CO}_{2}$ to $\mathrm{CO}$ can be achieved at a potential ca $300 \mathrm{mV}$ positive to that of an inert vitreous carbon electrode. The reduction of $\mathrm{CO}_{2}$ to $\mathrm{CO}$ catalyzed by cobalt porphyrin was carried out at $1.85 \mathrm{~V}$, but at p-type Si electrode it shifts more positive at $-1.55 \mathrm{~V}$ versus $\mathrm{Ag} / \mathrm{AgCl}$.

\section{Conflict of Interests}

The author declares that there is no conflict of interests regarding the publication of this paper.

\section{Acknowledgments}

The author would like to thank Research Deanship, University of Hail, Kingdom of Saudi Arabia, for providing research fund (SC14012). The author also thanks Dr. Saravanan Rajendrasozhan, University of Hail, Saudi Arabia, for his assistance in paper preparation.

\section{References}

[1] Ø. Hatlevik, M. C. Blanksma, V. Mathrubootham, A. M. Arif, and E. L. Hegg, "Modeling carbon monoxide dehydrogenase/acetyl-CoA synthase (CODH/ACS): a trinuclear nickel complex employing deprotonated amides and bridging thiolates," Journal of Biological Inorganic Chemistry, vol. 9, no. 2, pp. 238-246, 2004.

[2] T. C. Harrop and P. K. Mascharak, "Structural and spectroscopic models of the A-cluster of acetyl coenzyme a synthase/carbon monoxide dehydrogenase: nature's Monsanto acetic acid catalyst," Coordination Chemistry Reviews, vol. 249, no. 24, pp. 30073024, 2005.

[3] J. S. Silvia and C. C. Cummins, "Ligand-based reduction of $\mathrm{CO}_{2}$ to $\mathrm{CO}$ mediated by an anionic niobium nitride complex," Journal of the American Chemical Society, vol. 132, no. 7, pp. 2169-2171, 2010.

[4] Z. Thammavongsy, T. Seda, L. N. Zakharov, W. Kaminsky, and J. D. Gilbertson, "Ligand-based reduction of $\mathrm{CO}_{2}$ and subsequent release of CO on iron(II)," Inorganic Chemistry, vol. 51, no. 17, pp. 9168-9170, 2012.

[5] W. Lin, H. Han, and H. Frei, " $\mathrm{CO}_{2}$ splitting by $\mathrm{H}_{2} \mathrm{O}$ to $\mathrm{CO}$ and $\mathrm{O}_{2}$ under UV light in TiMCM-41 silicate sieve," The Journal of Physical Chemistry B, vol. 108, no. 47, pp. 18269-18273, 2004.

[6] S. Sato, K. Koike, H. Inoue, and O. Ishitani, "Highly efficient supramolecular photocatalysts for $\mathrm{CO}_{2}$ reduction using visible light," Photochemical and Photobiological Sciences, vol. 6, no. 4, pp. 454-461, 2007.

[7] T. Ohnishi, H. Seino, M. Hidai, and Y. Mizobe, "The C=O and $\mathrm{C}=\mathrm{S}$ bond cleavage in carbon dioxide and tolyl isothiocyanate by reactions with the $\mathrm{Mo}(0)$ tetraphosphine complex [Mo $\left\{\right.$ meso-o- $\left.\left.\mathrm{C}_{6} \mathrm{H}_{4}\left(\mathrm{PPhCH}_{2} \mathrm{CH}_{2} \mathrm{PPh}_{2}\right)_{2}\right\}\left(\mathrm{Ph}_{2} \mathrm{PCH}_{2} \mathrm{CH}_{2} \mathrm{PPh}_{2}\right)\right]$," Journal of Organometallic Chemistry, vol. 690, no. 5, pp. 11401146, 2005.

[8] A. J. Morris, G. J. Meyer, and E. Fujita, "Molecular approaches to the photocatalytic reduction of carbon dioxide for solar fuels," Accounts of Chemical Research, vol. 42, no. 12, pp. 1983-1994, 2009.

[9] E. E. Barton, D. M. Rampulla, and A. B. Bocarsly, "Selective solar-driven reduction of $\mathrm{CO}_{2}$ to methanol using a catalyzed pGaP based photoelectrochemical cell," Journal of the American Chemical Society, vol. 130, no. 20, pp. 6342-6344, 2008.

[10] B. Kumar, J. M. Smieja, and C. P. Kubiak, "Photoreduction of $\mathrm{CO}_{2}$ on p-type silicon using $\mathrm{Re}\left(\right.$ bipy- $\left.\mathrm{Bu}^{\mathrm{t}}\right)(\mathrm{CO})_{3} \mathrm{Cl}$ : Photovoltages exceeding $600 \mathrm{mV}$ for the selective reduction of $\mathrm{CO}_{2}$ to CO," The Journal of Physical Chemistry C, vol. 114, no. 33, pp. 14220-14223, 2010.

[11] M. Jitaru, D. A. Lowy, M. Toma, B. C. Toma, and L. Oniciu, "Electrochemical reduction of carbon dioxide on flat metallic cathodes," Journal of Applied Electrochemistry, vol. 27, no. 8, pp. 875-889, 1997.

[12] G. A. Olah, A. Goeppert, and G. K. S. Prakash, "Chemical recycling of carbon dioxide to methanol and dimethyl ether: 
from greenhouse gas to renewable, environmentally carbon neutral fuels and synthetic hydrocarbons," The Journal of Organic Chemistry, vol. 74, no. 2, pp. 487-498, 2009.

[13] B. Kumar, M. Llorente, J. Froehlich, T. Dang, A. Sathrum, and C. P. Kubiak, "Photochemical and photoelectrochemical reduction of $\mathrm{CO}_{2}$," Annual Review of Physical Chemistry, vol. 63, pp. 541569, 2012.

[14] Y.-Y. Ohnishi, Y. Nakao, H. Sato, and S. Sakaki, "Ruthenium(II)catalyzed hydrogenation of carbon dioxide to formic acid. Theoretical study of significant acceleration by water molecules," Organometallics, vol. 25, no. 14, pp. 3352-3363, 2006.

[15] P. Kurz, B. Probst, B. Spingler, and R. Alberto, "Ligand variations in $\left[\mathrm{ReX}(\right.$ diimine $\left.)(\mathrm{CO})_{3}\right]$ complexes: effects on photocatalytic $\mathrm{CO}_{2}$ reduction," European Journal of Inorganic Chemistry, vol. 2006, no. 15, pp. 2966-2974, 2006.

[16] B. J. Fisher and R. Eisenberg, "Electrocatalytic reduction of carbon dioxide by using macrocycles of nickel and cobalt," Journal of the American Chemical Society, vol. 102, no. 24, pp. 7361-7363, 1980.

[17] E. E. Benson, C. P. Kubiak, A. J. Sathrum, and J. M. Smieja, "Electrocatalytic and homogeneous approaches to conversion of $\mathrm{CO}_{2}$ to liquid fuels," Chemical Society Reviews, vol. 38, no. 1, pp. 89-99, 2009.

[18] K. Alenezi, "Solar light-driven reduction of $\mathrm{CO}_{2}$ on $\mathrm{p}$ type silicon semiconducting electrodes by iron(0)pentaflourotetraphenylporphyrin," International Journal of Electrochemical Science, vol. 10, no. 5, pp. 4279-4289, 2015.

[19] M. Gattrell, N. Gupta, and A. Co, "A review of the aqueous electrochemical reduction of $\mathrm{CO}_{2}$ to hydrocarbons at copper," Journal of Electroanalytical Chemistry, vol. 594, no. 1, pp. 1-19, 2006.

[20] K. Hara and T. Sakata, "Large current density $\mathrm{CO}_{2}$ reduction under high pressure using gas diffusion electrodes," Bulletin of the Chemical Society of Japan, vol. 70, no. 3, pp. 571-576, 1997.

[21] Y. Hori, H. Ito, K. Okano, K. Nagasu, and S. Sato, "Silver-coated ion exchange membrane electrode applied to electrochemical reduction of carbon dioxide," Electrochimica Acta, vol. 48, no. 18, pp. 2651-2657, 2003.

[22] K. Hara and T. Sakata, "Electrocatalytic formation of $\mathrm{CH}_{4}$ from $\mathrm{CO}_{2}$ on a Pt gas-diffusion electrode," Journal of the Electrochemical Society, vol. 144, no. 2, pp. 539-545, 1997.

[23] R. H. Crabtree, Ed., Inorganic Chemical Strategies for a Warming World, JohnWiley \& Sons, New York, NY, USA, 2010.

[24] T. R. O’Toole, L. D. Margerum, T. D. Westmoreland, W. J. Vining, R. W. Murray, and T. J. Meyer, "Electrocatalytic reduction of $\mathrm{CO}_{2}$ at a chemically modified electrode," Journal of the Chemical Society, Chemical Communications, no. 20, pp. 1416-1417, 1985.

[25] E. Portenkirchner, K. Oppelt, C. Ulbricht et al., "Electrocatalytic and photocatalytic reduction of carbon dioxide to carbon monoxide using the alkynyl-substituted rhenium(I) complex $\left(5,5^{\prime}\right.$-bisphenylethynyl-2,2' -bipyridyl) $\operatorname{Re}(\mathrm{CO})_{3} \mathrm{Cl}$," Journal of Organometallic Chemistry, vol. 716, pp. 19-25, 2012.

[26] J. Hawecker, J. M. Lehn, and R. Ziessel, "Efficient photochemical reduction of $\mathrm{CO}_{2}$ to $\mathrm{CO}$ by visible light irradiation of systems containing $\operatorname{Re}($ bipy $)(\mathrm{CO})_{3} \mathrm{X}$ or $\mathrm{Ru}(\text { bipy })_{3}^{2+}-\mathrm{Co}^{2+}$ combinations as homogeneous catalysts," Journal of the Chemical Society, Chemical Communications, no. 9, pp. 536-538, 1983.

[27] H. Hori, F. P. A. Johnson, K. Koike, O. Ishitani, and T. Ibusuki, "Efficient photocatalytic $\mathrm{CO}_{2}$ reduction using $\left[\operatorname{Re}(\mathrm{bpy})(\mathrm{CO})_{3}\left\{\mathrm{P}(\mathrm{OET})_{3}\right\}\right]^{+}$," Journal of Photochemistry and Photobiology A: Chemistry, vol. 96, no. 1-3, pp. 171-174, 1996.
[28] T. Morimoto, T. Nakajima, S. Sawa, R. Nakanishi, D. Imori, and O. Ishitani, " $\mathrm{CO}_{2}$ capture by a rhenium(I) complex with the aid of triethanolamine," Journal of the American Chemical Society, vol. 135, no. 45, pp. 16825-16828, 2013.

[29] H. Hori, F. P. A. Johnson, K. Koike, K. Takeuchi, T. Ibusuki, and O. Ishitani, "Photochemistry of $\left[\operatorname{Re}(\text { bipy })(\mathrm{CO})_{3}\left(\mathrm{PPh}_{3}\right)\right]^{+}$(bipy $=2,2^{\prime}$-bipyridine) in the presence of triethanolamine associated with photoreductive fixation of carbon dioxide: participation of a chain reaction mechanism," Journal of the Chemical SocietyDalton Transactions, no. 6, pp. 1019-1023, 1997.

[30] H. Takeda, K. Koike, H. Inoue, and O. Ishitani, “Development of an efficient photocatalytic system for $\mathrm{CO}_{2}$ reduction using rhenium(I) complexes based on mechanistic studies," Journal of the American Chemical Society, vol. 130, no. 6, pp. 2023-2031, 2008.

[31] M. D. Doherty, D. C. Grills, J. T. Muckerman, D. E. Polyansky, and E. Fujita, "Toward more efficient photochemical $\mathrm{CO}_{2}$ reduction: use of $\mathrm{scCO}_{2}$ or photogenerated hydrides," Coordination Chemistry Reviews, vol. 254, no. 21-22, pp. 2472-2482, 2010.

[32] V. Balzani, Ed., Supramolecular Photochemistry, D. Reidel Publishing Company, Dordrecht, The Netherlands, 1987.

[33] C. Bruckmeier, M. W. Lehenmeier, R. Reithmeier, B. Rieger, J. Herranz, and C. Kavakli, "Binuclear rhenium(I) complexes for the photocatalytic reduction of $\mathrm{CO}_{2}$," Journal of the Chemical Society, Dalton Transactions, vol. 41, no. 16, pp. 5026-5037, 2012.

[34] R. M. Berger and D. D. Ellis II, "Unusual electrochemical and spectroscopic behavior in a ligand-bridged binuclear complex of ruthenium (II): tetrakis (2,2' -bipyridine)- ( $\mu$-2,4,6-tris(2pyridyl)triazine)diruthenium(II)," Inorganica Chimica Acta, vol. 241, no. 2, pp. 1-4, 1996.

[35] M. R. Dubois and D. L. Dubois, "Development of molecular electrocatalysts for $\mathrm{CO}_{2}$ reduction and $\mathrm{H}_{2}$ production/oxidation," Accounts of Chemical Research, vol. 42, no. 12, pp. 1974-1982, 2009.

[36] C. D. Windle and R. N. Perutz, "Advances in molecular photocatalytic and electrocatalytic $\mathrm{CO}_{2}$ reduction," Coordination Chemistry Reviews, vol. 256, no. 21-22, pp. 2562-2570, 2012.

[37] J. Schneider, H. Jia, J. T. Muckerman, and E. Fujita, “Thermodynamics and kinetics of $\mathrm{CO}_{2}, \mathrm{CO}$, and $\mathrm{H}^{+}$binding to the metal centre of $\mathrm{CO}_{2}$ reduction catalysts," Chemical Society Reviews, vol. 41, no. 6, pp. 2036-2051, 2012.

[38] T. Yui, Y. Tamaki, K. Sekizawa, and O. Ishitani, "Photocatalytic reduction of $\mathrm{CO}_{2}$ : from molecules to semiconductors," Topics in Current Chemistry, vol. 303, pp. 151-184, 2011.

[39] C. Kutal, M. A. Weber, G. Ferraudi, and D. Geiger, "A mechanistic investigation of the photoinduced reduction of carbon dioxide mediated by tricarbonylbromo(2,2'-bipyridine)rhenium(I)," Organometallics, vol. 4, no. 12, pp. 21612166, 1985.

[40] B. Kumar, J. M. Smieja, A. F. Sasayama, and C. P. Kubiak, "Tunable, light-assisted co-generation of $\mathrm{CO}$ and $\mathrm{H}_{2}$ from $\mathrm{CO}_{2}$ and $\mathrm{H}_{2} \mathrm{O}$ by $\mathrm{Re}$ (bipy-tbu) $(\mathrm{CO})_{3} \mathrm{Cl}$ and $\mathrm{p}-\mathrm{Si}$ in non-aqueous medium," Chemical Communications, vol. 48, no. 2, pp. 272$274,2012$.

[41] K. Alenezi, S. K. Ibrahim, P. Li, and C. J. Pickett, "Solar fuels: photoelectrosynthesis of $\mathrm{CO}$ from $\mathrm{CO}_{2}$ at p-type $\mathrm{Si}$ using fe porphyrin electrocatalysts," Chemistry-A European Journal, vol. 19, no. 40, pp. 13522-13527, 2013.

[42] I. Bhugun, D. Lexa, and J.-M. Savéant, "Catalysis of the electrochemical reduction of carbon dioxide by iron $(0)$ porphyrins: 
synergystic effect of weak Brönsted acids," Journal of the American Chemical Society, vol. 118, no. 7, pp. 1769-1776, 1996.

[43] Y. Tamaki, K. Watanabe, K. Koike, H. Inoue, T. Morimoto, and O. Ishitani, "Development of highly efficient supramolecular $\mathrm{CO}_{2}$ reduction photocatalysts with high turnover frequency and durability," Faraday Discussions, vol. 155, pp. 115-127, 2012.

[44] A. J. Bard and L. R. Faulkner, Electrochemical Methods: Fundamentals and Applications, John Wiley \& Sons, New York, NY, USA, 2nd edition, 2001.

[45] L. R. Webster, S. K. Ibrahim, J. A. Wright, and C. J. Pickett, "Solar fuels: visible-light-driven generation of dihydrogen at p-type silicon electrocatalysed by molybdenum hydrides," ChemistryA European Journal, vol. 18, no. 37, pp. 11798-11803, 2012. 

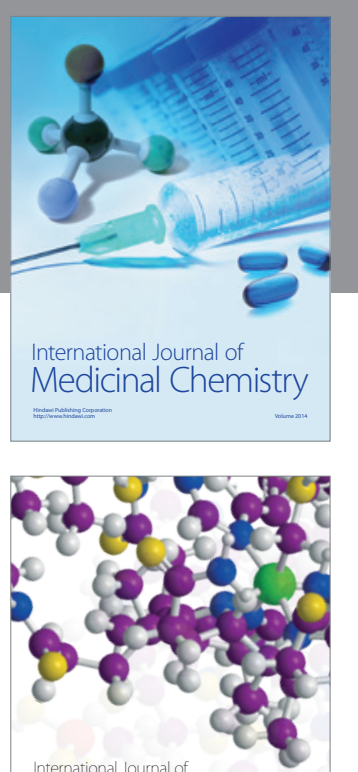

Carbohydrate Chemistry

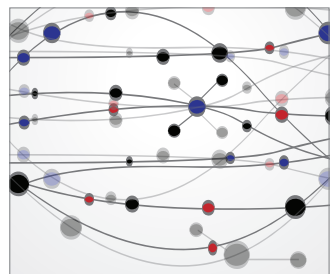

The Scientific World Journal
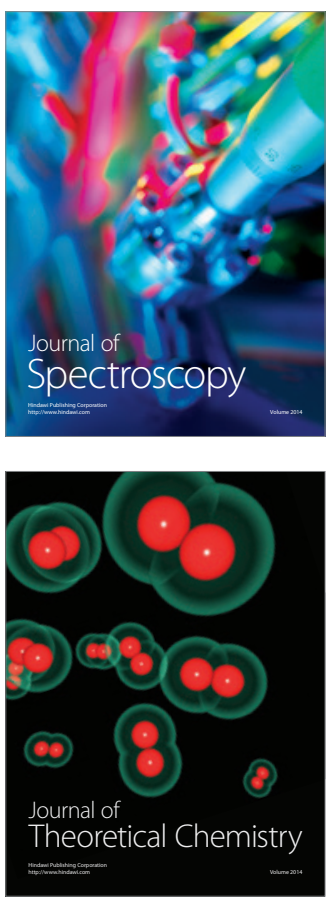
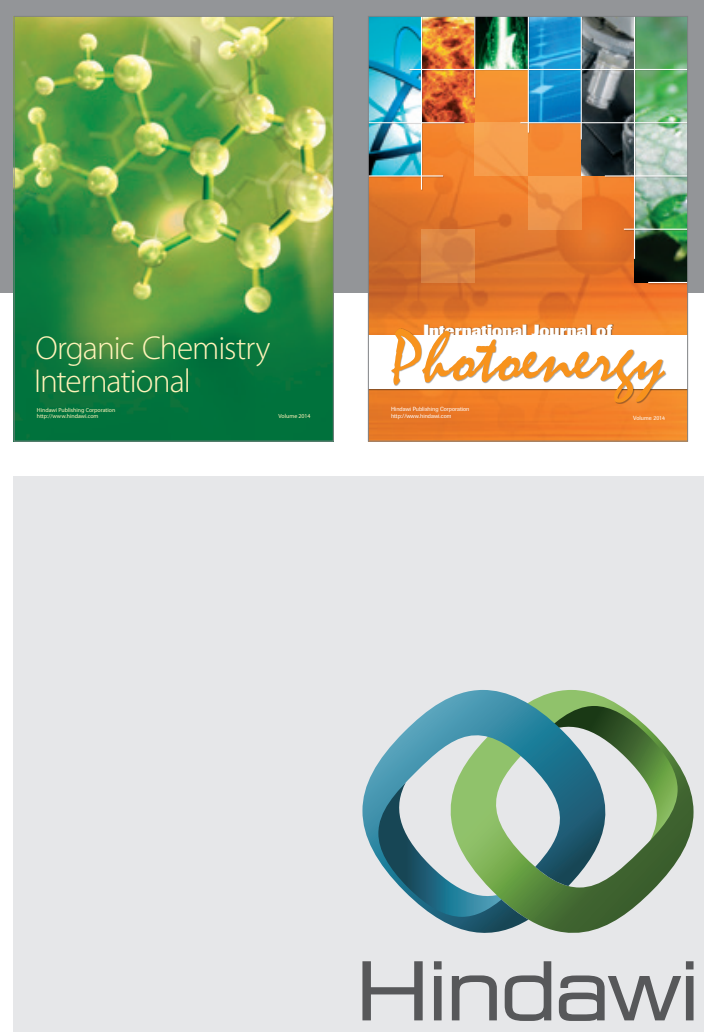

Submit your manuscripts at

http://www.hindawi.com

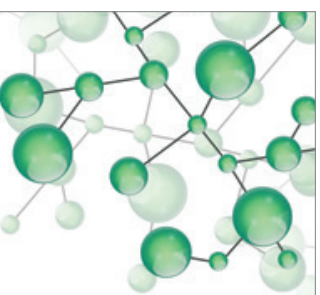

International Journal of

Inorganic Chemistry

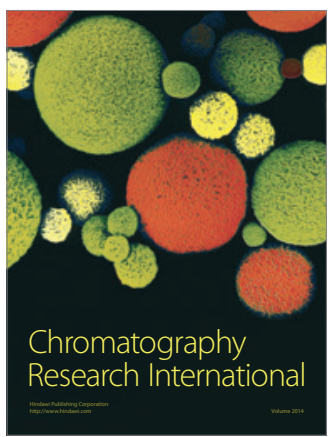

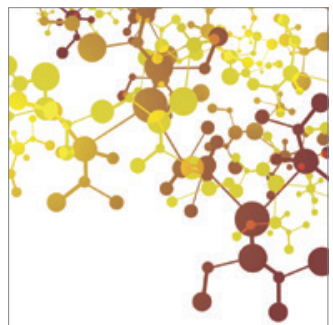

Applied Chemistry
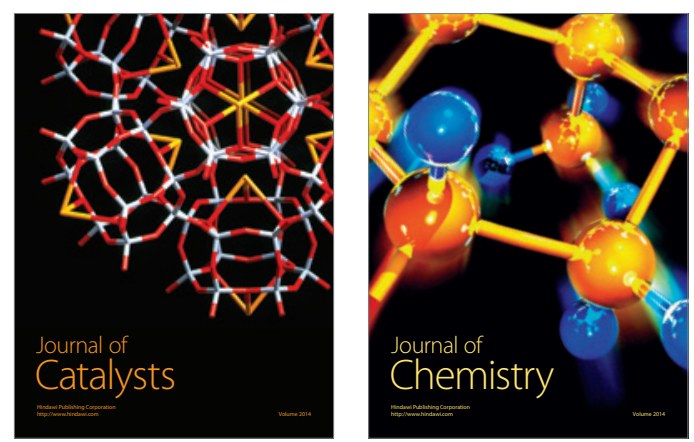
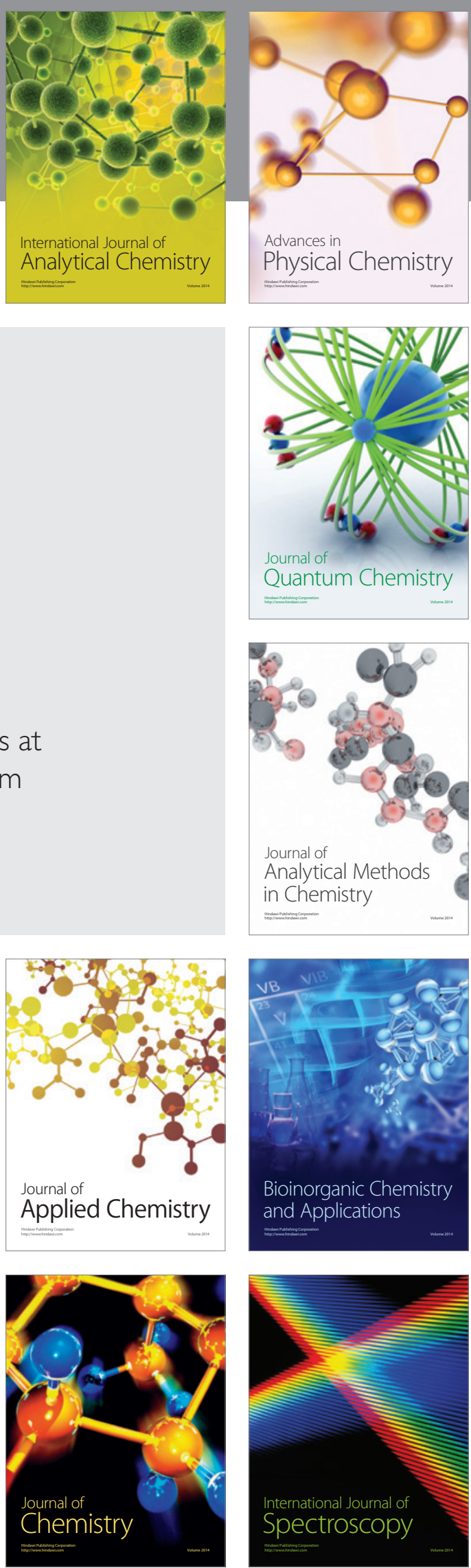